\title{
PEMETAAN ANCAMAN BENCANA BANJIR KECAMATAN SUNGAI SERUT, SEBAGI MEDIA PEMBELAJARAN TOPIK BAHASAN GLOBAL WARMING DI SMKN 3 KOTA BENGKULU
}

\author{
Eva Efriyani ${ }^{1 *}$, Nirwana ${ }^{2}$, M. Farid ${ }^{3}$ \\ ${ }^{1}$ Pascasarjana Pendidikan IPA FKIP Universitas Bengkulu, Bengkulu \\ ${ }^{2}$ Pendidikan Fisika FKIP Universitas Bengkulu, Bengkulu \\ ${ }^{3}$ Jurusan Fisika FMIPA Universitas Bengkulu, Bengkulu \\ *Email: efrie.epha@gmail.com
}

\begin{abstract}
ABSTRAK
Ada kecenderungan peningkatan kuantitas banjir yang terjadi di Kota Bengkulu dalam setiap tahunnya. Salah satu wilayah yang selalu mengalami bencana banjir adalah kecamatan Sungai Serut, khususnya wilayah Kelurahan Tanjung Agung, Tanjung Jaya dan Kelurahan Semarang. Banjir yang terjadi di wilayah tersebut tergolong tipe banjir karena tumpahan air sungai yang menggenang karena elevasi rendah. Pemetaan ancaman banjir di Kecamatan Sungai Serut dilakukan dengan mengukur ketinggian di setiap titik pengukuran, menggunakan GPS. Pengukuran jarak sungai terdekat dan jarak dari garis pantai dilakukan menggunakan google earth. Pemetaan wilayah terkena dampak dan ancaman banjir tidak saja penting untuk perencanaan wilayah, akan tetapi juga untuk media pembelajaran di sekolah. Pada proses pembelajaran tentang pemenasan global, banjir menjadi salah satu dampak yang terjadi kerenanya. Banjir yang terjadi di Kecamatan Sungai serut dapat ditelusuri kejadiannya karena debit Sungai Bengkulu yang sangat besar. Debit yang sangat besar tidak langsung ditampung oleh laut, karena pada saat itu laut dalam kondisi pasang. Kejadian laut pasang disaat musim penghujan mengindikasikan adanya anomali yang terjadi di laut, yang besar kemungkinan disebabkan karena dampak pemanasan global. Banjir sebagai media pada topik bahasan pemanasan global mampu meningkatkan hasil belajar pada konsep pemanasan global siswa ekstrakulikuler KIR SMK Negeri 3 Kota Bengkulu kelompok tinggi, sedang dan rendah. Hal ini di buktikan dengan nilai $\mathrm{N}$-gain untuk kelas tinggi adalah sebesar 0,75 dalam katagori tinggi, kelas sedang sebesar 0,52 dalam katagori sedang, dan kelas rendah sebesar 0,44 dalam katagori sedang.
\end{abstract}

Kata kunci: Banjir, potensi banjir, pemanasan global, hasil belajar.

\section{PENDAHULUAN}

Ancaman bencana banjir di Kota Bengkulu semakin tahun semakin meningkat terutama di wilayah sekitar sungai dan dekat dengan pantai. Farid (2017) menduga akan meningkatnya ancaman banjir di Kota Bengkulu. Dugaan akan meningkatnya ancaman bencana banjir di Kota Bengkulu semakin meyakinkan, ketika volume banjir tiap tahunnya selalu meningkat. Dengan meningkatnya volume air ini akan memberikan ancaman tersendiri untuk masyarakat Kota Bengkulu. Hasil penelitian membuktikan tingkat genangan air yang semakin meluas dan jumlah lokasi banjir yang semakin meningkat. Ancaman bencana banjir lebih banyak di wilayah yang masih dekat dengan pantai dan dekat dengan aliran sungai.

$$
\text { Banjir tidak hanya mengganggu }
$$
kenyamanan hidup manusia, akan tetapi juga berdampak pada laju pengiriman barang, merusak infrastruktur, mengganggu kesehatan, dan menghambat laju perekonomian, seperti ditunjukkan pada Gambar 1. 


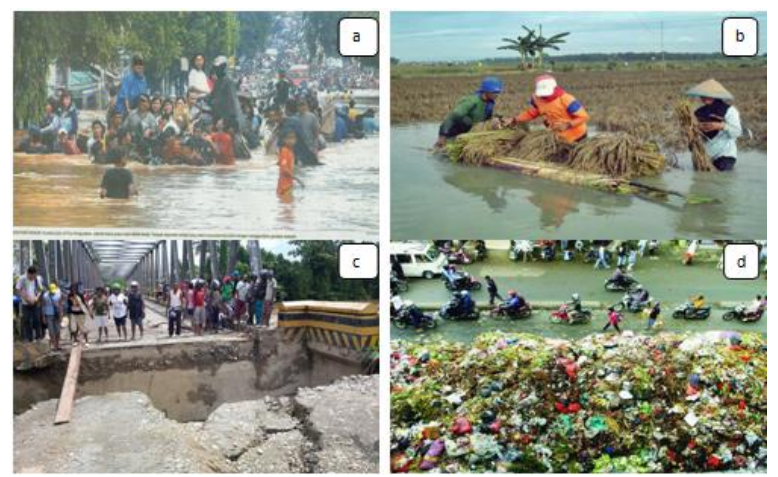

Gambar 1. a. Warga mengungsi karena banjir; b. Gagal panen; c. Jembatan putus; d. Sampah menjadi sarang penyakit

Masyarakat terpaksa mengungsi demi untuk menghindari bahaya yang lebih berat yang mengancam nyawa mereka. Banjir 2007 di Jakarta sedikitnya memakan korban 80 orang dinyatakan tewas selama 10 hari karena terseret arus, tersengat listrik, atau sakit. Tidak kurang dari 320.000 orang mengungsi (BMKG, 2007). Dampak banjir terhadap pertanian adalah terjadinya gagal panen seperti dinyatakan oleh Huho dan Kosonei (2014). Mereka meneliti tentang hubungan antara curah hujan dengan pertumbuhan ekonomi di Kenya. Hasil penelitian menujukkan adanya hubungan yang bernilai positif antara curah hujan yang normal dengan pertumbuhan ekonomi. Ketika terjadi bencana kekeringan masyarakat tidak dapat menjalankan fungsi pertaniannya, dan sebaliknya ketika terjadi bencana banjir maka yang terjadi adalah gagal panen, berjangkitnya wabah penyakit, dan rusaknya infrastruktur. Terjadi hubungan terbalik antara kuantitas bencana dengan pertumbuhan ekonomi.

Kerugian akibat banjir terhadap pertumbuhan ekonomi juga dinyatakan oleh Hasan dan Zaidi (2012) yang mengkaji tentang dampak bencana banjir yang terjadi pada tahun 2011 terhadap perekonomian Pakistan. Hasil kajian menunjukkan bahwa Banjir telah merugikan ekonomi Pakistan lebih dalam dengan kerugian ekonomi yang serius, karena sekitar $68 \%$ dari rakyat Pakistan tinggal di pengungsian dan tidak dapat beraktivitas dalam kegiatan yang membangkitkan perekonomian. Kajian dari Hasan dan Zaidi ini didukung oleh pernyataan Ismail dan Mustaquim (2013) yang menyatakan bahwa bencana banjir berdampak buruk pada status sosial-ekonomi mata pencaharian bagi rumah tangga di Chanchal sub-divisi dari distrik Malda dari Bengal Barat- India. Banjir juga dapat memberikan dampak buruk pada sektor lain seperti sektor kesehatan.

Kreimer dan Arnold (2000), dan Guha-Sapir et al, (2004) juga menjelaskan bahwa banjir di negara maju tidak banyak menyebabkan korban, kerusakan dan kerugian, sedangkan di negara berkembang korban, kerusakan dan kerugiannya jauh lebih banyak.

Kondisi alam yang akhir-akhir ini dialami di Provinsi Bengkulu adalah perubahan iklim yang akan cenderung menjadi bencana. Di wilayah lain perubahan iklim sudah menjadi bencana yang berpengaruh pada pertumbuhan ekonomi wilayah tersebut. Akram (2012) mengemukakan bahwa perubahan iklim yang ditunjukkan dengan berubahnya pola kenaikan suhu dan curah hujan adalah merupakan bencana yang akan menurunkan angka pertumbuhan ekonomi secara sigifikan di negara-negara Asia. Kwari et. al, (2015) melakukan studi tentang hubungan antara perubahan iklim dan bencana banjir dengan pertumbuhan ekonomi di Nigeria Utara. Hasil studi menunjukkan ada kecenderungan peningkatan perubahan iklim akan memperburuk terjadinya peristiwa cuaca ekstrim dan banjir dan secara signifikan menurunkan angka pertumbuhan ekonomi di wilayah tersebut. Dampak pada kegiatan sosial-ekonomi secara otomatis mempengaruhi stabilitas pertumbuhan ekonomi nasional.

Di sisi lain, kejadian banjir dapat digunakan untuk media pembelajaran, yaitu media untuk pengajaran atau ekstra kurikuler pada topik pemanasan global. Di kegiatan ektra kurikuler siswa telah dikenalkan dengan istilah pemanasan global (global warming). Global warming yang terjadi karena perilaku manusia di bumi kurang menjaga eksistensi keteraturan alam. Salah satu perilaku manusia yang kontra produktif adalah pembabatan hutan yang tidak terkendali. Akibat gundulnya hutan, tidak saja terjadi ketidakseimbangan hidrologi, akan tetapi juga terjadi ketidakseimbangan distribusi temperatur di permukaan bumi. Akibat yang terjadi dari ketidakseimbangan distribusi temperatur adalah perubahan iklim yang tidak teratur, cuaca ekstrim, kenaikan muka air laut, curah hujan yang berlebih, dan sebagainya. 
Curah hujan yang cenderung tinggi dan naiknya muka air laut akan memicu terjadinya banjir. Debit air sungai yang berlebih tidak dapat ditampung oleh laut, karena muka air laut naik (rob). Pada saat seperti ini tidak ada jalan lain bagi sungai kecuali menumpahkan debit airnya ke perkampungan di sekitar sungai dan terjadilah banjir. Kondisi seperti ini sering terjadi di Kota Bengkulu.

\section{METODE PENELITIAN}

Dalam penelitian ini digunakan alat untuk mengakuisisi data yaitu GPS, Software ArchGis, dan Google Earth. GPS digunakan untuk menentukan posisi dan elevasi, ArchGis untuk pembuatan peta, dan Google Earth untuk mengukur jarak dari sungai terdekat ke lokasi stasiun, dan jarak dari garis pantai ke stasiun. Data yang telah diperoleh kemudian diolah dengan cara memberikan skor. Data ketinggian diberikan skor dari 2 sampai 10. Semakin rendah elevasi dari suatu stasiun akan semakin besar skornya. Skor 10 diberikan untuk elevasi dari 0-5 meter, skor 8 untuk elevasi 5,1 - 10 meter, skor 6 untuk elevasi 10,1 - 15 meter, dan skor 4 untuk elevasi diatas 15 meter. Data jarak dari sungai terdekat diberikan skor dari 2 sampai 10. Semakin dekat dengan sungai semakin besar skornya. Skor 10 diberikan untuk jarak 0-200 meter, skor 8 untuk jarak 201-400 meter, skor 6 untuk jarak 401-600, skor 4 untuk jarak diatas 600 meter. Data jarak dari garis pantai diberikan skor dari 2 sampai 10. Semakin dekat dengan garis pantai semakin besar skornya. Skor 10 diberikan untuk jarak 0-400 meter, skor 8 untuk jarak 401-600 meter, skor 6 untuk jarak 601-800, skor 4 untuk jarak diatas 800 meter.

Skor elevasi, skor jarak pantai dan skor jarak dari garis pantai selanjutnya dijumlah untuk setiap lokasi. Pembuatan peta ancaman bahaya banjir dilakukan dengan menempatkan skor total pada setiap koordinat stasiun penelitian. Peta dibuat dengan ArcGis, dengan menempatkan skor total di setiap stasiun pada setiap koordinat. Hasilnya adalah peta potensi rawan bencana banjir dengan 3 warna, yaitu merah, kuning dan hijau. Warna merah menunjukkan ancaman tertinggi, warna kuning menunjukkan ancaman tinggi dan warna hijau menunjukkan ancaman rendah.
Peta yang terbentuk kemudian digunakan untuk media pembelajaran di SMKN 3 Kota Bengkulu pada pokok bahasan pemanasan global.

\section{HASIL DAN PEMBAHASAN}

Hasil penelitian tentang potensi ancaman bahaya banjir di Kecamatan Sungai Serut dituangkan dalam peta pada Gambar 2.

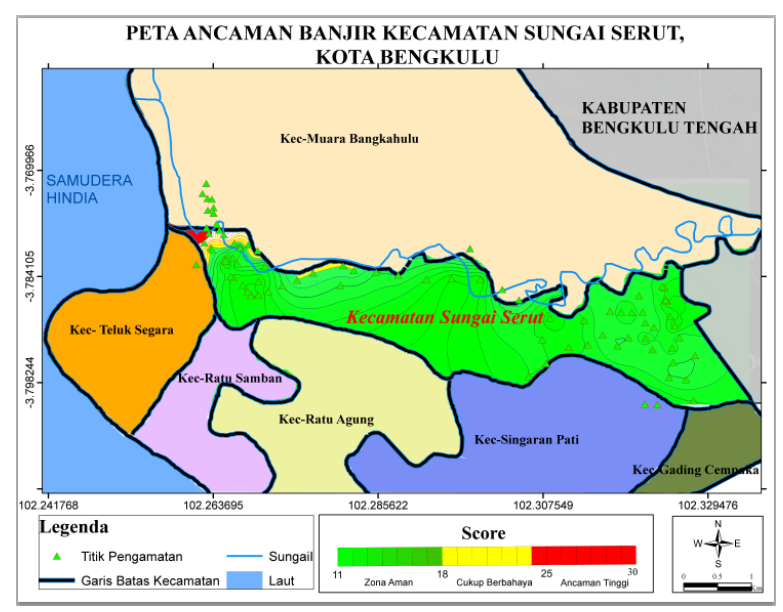

Gambar 2. Peta Ancaman BAnjir Kecamatan Sungai Serut Kota Bengkulu

Pada Gambar 2 tingkat ancaman bahaya banjir tertinggi diberi warna merah ada di wilayah yang sangat dekat dengan pantai. Secara teoritis wilayah tersebut memang sangat rentan terhadap ancaman banjir, selain karena mempunyai elevasi yang sangat rendah, juga sangat dekat dengan garis pantai. Kondisi tersebut membuktikan bahwa hipotesis yang mengatakan bahwa wilayah ancaman tertinggi untuk bahaya banjir ada di wilayah pesisir itu sendiri. Putra (2012) menyatakan bahwa Banjir rob telah menimbulkan pengaruh tehadap wilayah pesisir di kecamatan Pademangan seperti tergenangnya lahan secara $0,05 \mathrm{~km}^{2} \pm$ rutin seluas pada ketinggian pasang $200 \mathrm{~cm}$ dan 0.13 $\mathrm{km}^{2}$ pada ketinggian pasang $250 \mathrm{~cm}$ Kedalaman banjir bervariasi, dari yang terendah hingga lebih dari $1 \mathrm{~m}$.

Jumlah titik data data yang mewakili warna merah ada sekitar 7 titik, atau sekitar 8,6\%. Jumlah ini pun semuanya terletak di tepi pantai yang menunjukkan bahwa di pantai tersebut selain sangat dekat pantai juga memiliki elevasi yang sangat rendah. Tidak semua daerah pantai 
memiliki elevasi rendah. Farid (2013) mengemukakan ada beberapa jenis pantai yang salah satunya adalah pantai bertebing. Tentu saja pantai bertebing ini memiliki elevasi yang tinggi sehingga memiliki kerentanan rendah terhadap ancaman banjir. Selain pantai tersebut bertebing juga jauh dari sungai terdekat, oleh karenanya memiliki skor yang rendah jika dijumlahkan dengan skor ketinggian dan skor jarak pantai.

Ancaman dibawahnya pada peta diberi warna kuning memanjang sepanjang jalan raya di Kelurahan Tanjung Jaya dan Kelurahan Semarang. Kenyataan menunjukkan setiap tahun pada musim penghujan wilayah tersebut sering dilanda banjir. Teori yang menyatakan bahwa tingkat ancaman bahaya banjir selalu mengancam pada wilayah-wilayah yang tergolong rendah dihitung dari permukaan laut dapat dibuktikan di wilayah ini. Hasil skoring di Kelurahan Tanjung Jaya dan Kelurahan Semarang termasuk tinggi, sehingga memiliki ancaman bencana banjir yang tinggi pula. Antara perhitungan secara survei, teoritik dan kenyataan terjadi kesesuaian di wilayah kedua kelurahan ini. Jumlah titik yang mewakili warna kuning ada sekitar 13 titik atau sekitar 13,1\%. Jumlah ini tidak terlalu besar, akan tetapi hampir setiap tahun di titik-titik ini terjadi banjir nyata. Karakteristik banjir yang terjadi seperti ditunjukkan dalam Gambar 4.3 adalah memanjang di sekitar aliran sungai. Banjir ini tidak hanya terjadi karena faktor elevasi, akan tetapi lebih sering terjadi karena limpahan air sungai yang ada di wilayah tersebut. Banjir yang terjadi karena limpahan air sungai ini juga dikemukakan oleh Sahrizal dkk (2016) bahwa Banjir yang terjadi di Kelurahan Cengkareng Timur dan Kapuk disebabkan oleh 4 faktor, yaitu luapan air sungai, banjir kiriman, saluran air yang buruk, dan air rob. Karakteristik banjir di kedua wilayah berbeda-beda. Ketinggian banjir di Kelurahan Cengkareng Timur paling rendah mencapai 10-20 cm sedangkan Kelurahan Kapuk paling rendah mencapai $20-30 \mathrm{~cm}$. Lamanya banjir di Kelurahan Cengkareng Timur selama 2 hari sedangkan Kelurahan Kapuk selama 7 hari. Luasan banjir selalu bertambah dari tahun ke tahun.

Hasil penelitian ini sejalan dengan penelitian Farid (2017) yang menyatakan bahwa ancaman wilayah yang terkena banjir di Kota
Bengkulu selalu bertambah setiap tahunnya. Ancaman yang selalu pasti menimbulkan bahya banjir di Kota Bengkulu adalah Kelurahan Tanjung Jaya, Kelurahan Tanjung Agung, Kelurahan Semarang dan Kelurahan Rawa Makmur yang karakternya lebih karena luapan air sungai yang terhambat masuk ke laut. Penelitian Himawan (2010) menguatkan hasil penelitian ini yaitu banjir yang terjadi di Kelurahan Tanjung Agung bersifat permanen dan hanya merupakan genangan, oleh karena masyarakat di wilayah tersebut tidak mau diungsikan maupun dipindahkan. Baik Farid (2017) maupun Himawan (2010) sama-sama memberikan informasi bahwa wilayah Kelurahan Tanjung Agung Kecamatan Sungai Serut merupakan wilayah yang selalu dilanda banjir dalam setiap tahunnya. Jika dinyatakan dalam grafik tingkat ancaman banjir di Kecamatan Sungai Serut dituangkan dalam grafik pada Gambar 3.

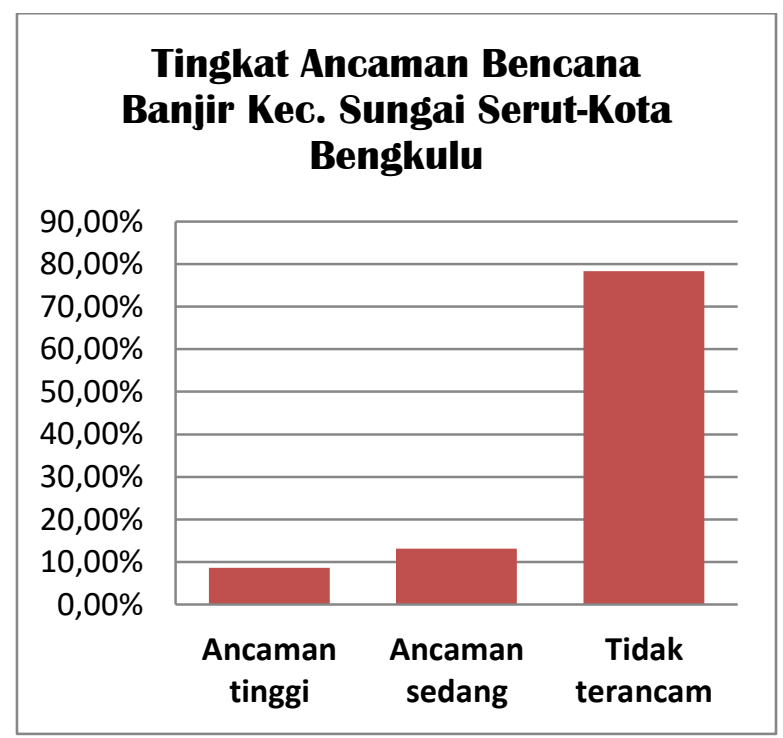

Gambar 3. Tingkat ancaman bencana banjir Kec. Sungai Serut

Pembelajaran tentang banjir, dampak banjir, pemetaan rawan banjir, dan sebab-sebab terjadinya banjir sangat relevan untuk diajarkan pada siswa sekolah sebagai bekal kemampuan melakukan dan memikirkan langkah mitigasi di lingkungannya. Setelah dilakukan pembelajaran selanjutnya dilakukan evaluasi. Evaluasi dilakukan untuk kelas ekstra kurikuler Karya Ilmiah Remaja (KIR) SMKN 3 Kota Bengkulu 
pada tanggal 24-28 April 2017 yang dijadikan sebagai bahan penelitian juga. Jumlah siswa pada kelas ini 30 orang yang terdiri dari 17 orang perempuan dan 13 orang laki-laki. Evaluasi ini dijadikan sebagai bahan penelitian untuk mengetahui tingkat kemajuan siswa setelah mengetahui tingkat potensi ancaman bencana banjir di Kota Bengkulu.

Proses pembelajaran pada penelitian ini menerapkan model Pembelajaran Problem Based Learning yang terdiri dari lima sintaks, yaitu (1) orientasi siswa pada masalah, (2) mengorganisasi siswa untuk belajar, (3) membimbing pengalaman individual/kelompok, mengembangkan dan menyajikan hasil karya, dan (5) menganalisis dan mengevaluasi proses pemecahan masalah.

Untuk mengetahui peningkatan hasil belajar, siswa diberi soal pretest untuk mengukur kemampuan awal siswa dan soal posttest untuk mengukur kemampuan akhir siswa setelah pembelajaran.

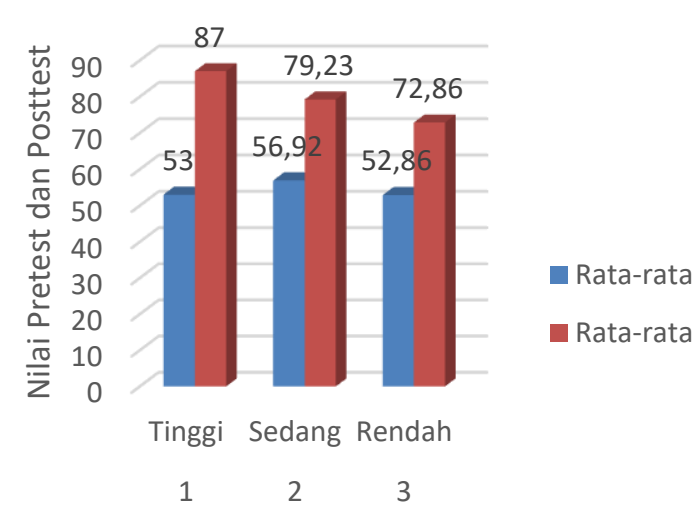

Gambar 4. Grafiknilai rata-rata tes awal dan tes akhir

\section{KESIMPULAN}

Berdasarkan hasil penelitian dan pembahasan dapat ditarik kesimpulan bahwa :

1. Daerah terancam bencana banjir tertinggi di Kecamatan Sungai Serut sesuai dengan peta adalah daerah pantai dan daerah tearancam di bawahnya adalah Kelurahan Tanjung Agung, dan Kelurahan Semarang. Daerah terancam banjir sesuai peta ini selaras dengan kenyataan banjir yang terjadi di daerah tersebut. Dengan kenyataan ini maka hipotesis yang menyatakan bahwa wilayah terancam banjir ada apada daerah dengan elevasi rendah, dekat dengan aliran sungai dan dekat dengan garis pantai.

2. Terdapat peningkatan hasil belajar pada konsep pemanasan global siswa ekstrakulikurel KIR SMK Negeri 3 Kota Bengkulu kelompok tinggi, sedang dan rendah. Hal ini dibuktikan dengan nilai $\mathrm{N}$ gain untuk kelas tinggi adalah sebesar 0,75 dalam katagori tinggi, kelas sedang sebesar 0,52 dalam katagori sedang, dan kelas rendah sebesar 0,44 dalam katagori sedang.

\section{DAFTAR PUSTAKA}

Akram-Lodhi, A. H., \& Kay, C. (Eds.). (2012). Peasants and globalization: Political economy, agrarian transformation and development. Routledge.

Farid, M., Brotopuspito, K. S., Wahyudi, S., \& Suryanto, W. (2013). The relationships among ground shear strain, shore characteristics and abrasion on the west coast of Bengkulu Province, Indonesia.

Farid.M, Sunarto, Suryanto.W. (2017). Investigation Of Flood Potential Areas in Bengkulu City. the 7th Annual Basic Science International Conference (BaSIC 2017), 7-8

Guha-Sapir, D., Hargitt, D., \& Hoyois, P. (2004). Thirty years of natural disasters 1974-2003: The numbers. Presses univ. de Louvain.

Himawan. G. (2010). Penyebab Tetap Bermukimnya Masyarakat Di Kawasan Rawan Banjir Kelurahan Tanjung Agung Kota Bengkulu. Tesis Program Pascasarjana Magister Teknik Pembangunan Wilayah Dan Kota Universitas Diponegoro Semarang 2010.

Huho, J. M., \& Kosonei, R. C. (2014). Understanding Extreme Climatic Events for Economic Development in Kenya. IOSR Journal of Environmental Science, Toxicology and Food Technology, 8(2), 1424.

Ismail, MD dan MD. Mustaquim. (2013). SocioEconomic Status Of population In Flood Prone Areas Of Chanchal Sub-Division In Malda District, West Bengal. Vol.1, issue 3, Aug 2013, 141-152.Diakses, 01 Juni 2016.

Kreimer, A., \& Arnold, M. (Eds.). (2000). Managing disaster risk in emerging 
economies (Vol. 2). World Bank Publications.

Kwari, J. W., Ayuba, S., \& Denis, L. D. (2015). Cross case assessment of the impacts of flooding on socio-economic development and agriculture in Kogi state. International Journal, 3(8), 146-155.

Puslitbang, B. M. K. G. (2007). Kajian Cuaca Ekstrim di Wilayah Indonesia. Laporan Penelitian, Pusat Penelitian dan Pengembangan, Badan Meteorologi Klimatologi dan Geofisika, Jakarta.

Putra, D. R., \& Marfai, M. A. (2012). Identifikasi Dampak Banjir Genangan (Rob) Terhadap Lingkungan Permukiman Di Kecamatan Pademangan Jakarta Utara. Jurnal Bumi Indonesia, 1(1).

Sahrizal Malki Darmawan1, Suprajaka2 1. (2016). ANALISIS TINGKAT RISIKO BENCANA BANJIR PADA KAWASAN PERMUKIMAN (Studi Kasus: Kelurahan Cengkareng Timur dan Kapuk. Program Studi Perencanaan Wilayah dan Kota, Universitas Esa Unggul 2Badan Informasi Geospasial (BIG) Jln. Arjuna Utara Tol Tomang Kebon Jeruk, Jakarta 11510. 